\title{
The Effect of Cigarette Smoking on Serum Liver Enzymes in Baghdad
}

\author{
Wasan Qasim Turki \\ wasan.turki@almustafafauniversity.edu.iq \\ Department of Medical Laboratory Techniques, Al-Mustafa University College, Baghdad, Iraq.
}

\begin{abstract}
Smoking is the most noticeably horrible human conduct; it is rehearsed by individuals dependent on nicotine numerous hurtful sicknesses, for example, cancer and liver disorder are brought about by smoking cigarettes. So this study aimed to study some of the liver function represented by the enzymes aspartate aminotransferase (AST or GOT) and alanine aminotransferase (ALT or GPT) in smokers and non-smokers for 50 persons in a group consists of 25 smokers and 25 non-smokers of different ages and to study the effectiveness of cigarette smoking on liver enzymes by checking the secretion of (AST) (35.84 \pm 4.1$) \mathrm{U} / 1$ $(A L T)(51.08 \pm 7.286) \mathrm{U} / 1(\mathrm{p}<0.05)$ relative to non-smokers were significantly correlated with heavy cigarette smoking.
\end{abstract}

Keywords: Smokers, Liver enzyme, Cigarette, Tobacco.

\section{Introduction}

Many diseases are caused by Smoking, and because of the risk of smoking, one person dies in the world per six minutes [1]. More than 4000 chemicals are present in tobacco smoke [2] and various hazardous substances like nicotine, free extremists, carbon monoxide, and other gaseous materials are submitted to a cigarette smoker [3]. That can lead to various degenerative pulmonary cardiovascular diseases and cancer. Cigarette smoking has been embroiled as a huge danger factor for the tobacco smoke contains various mixes, huge numbers of which are oxidants and favorable to oxidants fit for creating free extremists and improving the oxidative stress in vivo [4] (Preston, 1991). The liver, which has several duties, is an essential organ. The liver is responsible, among other things, for removing narcotics, alcohol, and other toxins from the body to remove them. The liver is one of the organs that are not directly affected by smoking so Heavy smoking creates toxins that stimulate necroinflammation and rise the dangerousness of hepatic lesions (fibrosis and activity scores) that related to hepatitis $\mathrm{C}$ virus (HCV) or hepatitis B virus (HBV) infection [5, 6]. Three main adverse effects on the liver are caused by smoking: direct or indirect harmful impact, immunological effects, and tumorigenesis effects. Smoking can cause a Direct toxic effect when produced chemicals with the potential for cytotoxicity [7]. Some Chemicals caused by smoking lead to oxidative stress linked to lipid peroxidation $[8,9]$. Where it stimulates the production of stellar cells and the growth of fibrosis. Cigarette smoke also helps in the production of pro-inflammatory cytokines that are related to liver cell damage (IL-1, IL-6, and TNF-alpha) [10]. Heavy cigarettes are related to carboxyhaemoglobin and lowered ability of red blood cells (RBC) to carrying oxygen, contributing to tissue hypoxia. Hypoxia promotes the development of erythropoietin, which causes bone marrow hyperplasia. This leads to the production of secondary polycythemia, which in turn increases the mass and turnover of red cells. This enhances catabolic iron resulting from both old red blood cells and iron produced For more information about the Conference please visit the websites: 
from elevated red cell destruction associated with polycythemia [11, 12]. In addition, erythropoietin promotes iron absorption from the intestine. Both elevated catabolic iron and high iron absorption lead to its concentration in macrophages over time and then in hepatocytes, inducing oxidative stress in hepatocytes [13]. Subsequently, the reason for this examination is to inspect the differences of liver enzymes among smokers than non-smokers in males and clarify the negative impacts of tobacco when smoking for long periods and the extent of its impact on the liver.

\section{Materials Method}

Blood samples are taken during February from (50) healthy male subjects in Baghdad, AlRusafa whose ages ranged from 20 to 55 years of age and divided into two groups, with 25 smoking persons and 25 non-smoking persons with varying smoking durations in the second group. We had to make sure that the volunteer had no illness before taking the sample to prevent cases that could rise liver enzyme secretion and interfere with the results of our study. The two groups (smoking persons and non-smoking persons) were chosen at close ages to be appropriate for the statistical study. People under the test are divided into smokers (who are smoking more than (20) cigarette daily) $(\mathrm{n}=25)$ and non-smokers $(\mathrm{n}=25) .5 .0 \mathrm{ml}$ of blood were taken from each participant, and this $5.0 \mathrm{ml}$ of venous blood were drowning by venipuncture using antiseptic for the skin (70\%alcohol), and then the samples placed in a heparinized tube, after that we made centrifugation to the blood samples at about three thousand, then the enzymes AST and ALT were estimated. In current experiments used ABBOTT C4000 Chemistry Analyzer to detect AST and ALT. To determine substantial differences and all the differences, the statistical assessment was carried out by statistical package for social sciences (spss) 26.0 and found the significant differences between the values (Mean \pm SEM) of the test and the control groups, t-test (at $\mathrm{p}<0.05)$ was applied.

\section{Results and Discussion}

The results showed that high concentrations of aspartate aminotransferase (AST or GOT) and alanine aminotransferase (ALT or GPT) compared to non-smokers $\mathrm{p}<0.05$ (Table 1) were significantly associated with heavy cigarette smoking (ALT).

Table 1. Concentrations AST and ALT enzymes of smokers compared with non-smoker.

\begin{tabular}{|c|c|c|c|c|}
\hline Parameters & $\begin{array}{c}\text { Smoking } \\
\mathbf{N}=\mathbf{2 5}\end{array}$ & $\begin{array}{c}\text { Non-smoking } \\
\mathbf{N = 2 5}\end{array}$ & P-value & $\begin{array}{c}\text { Significant } \\
\mathbf{p}<\mathbf{0 . 0 5}\end{array}$ \\
\hline AST or GOT (U/I ) & $35.84 \pm 4.1$ & $19.20 \pm 1.534$ & 0.006 & S* \\
\hline ALT or GPT (U/I ) & $51.08 \pm 7.286$ & $25.72 \pm 1.837$ & 0.001 & $S^{*}$ \\
\hline *S= Significant
\end{tabular}

Figure (1) and Figure (2) show that both AST and ALT have a higher level in smokers if we compare them with non-smokers where $(\mathrm{p}<0.05)$. According to the results in Figure (1). Height of the concentrations of aspartate aminotransferase (AST or GOT) and alanine aminotransferase (ALT or GPT) because of the intensity of tobacco smoke and its harmful substance affected on liver cells, prompting the emission of liver enzyme (AST) and (ALT) through inflammatory pathways or exacerbating the pathogenic effects of other compounds on

For more information about the Conference please visit the websites: 
the liver [14]. Furthermore, that may occur due to nitrosative stress, which is a disorder that arises when the processing of chemicals containing highly reactive, such as nitrous oxide, exceeds the human body's capacity to neutralize and remove them. Nitrosative stress able to run the reactions that convert the structure of proteins so interfere with normal body functions $[15,16]$. Cigarette smoke contains a large number of hepatotoxic chemicals, like nicotine [7].

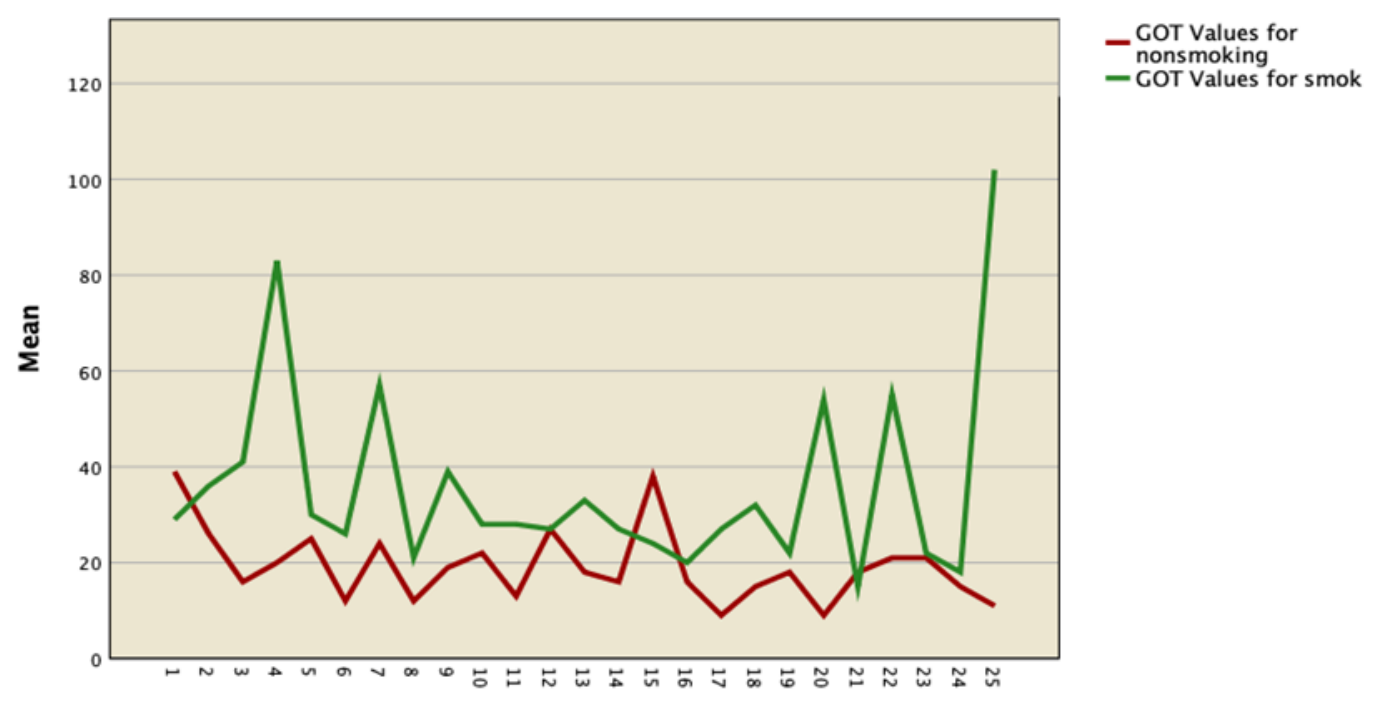

ID

Figure 1. Concentrations (AST or GOT) enzymes of smokers compared with non-smoker.

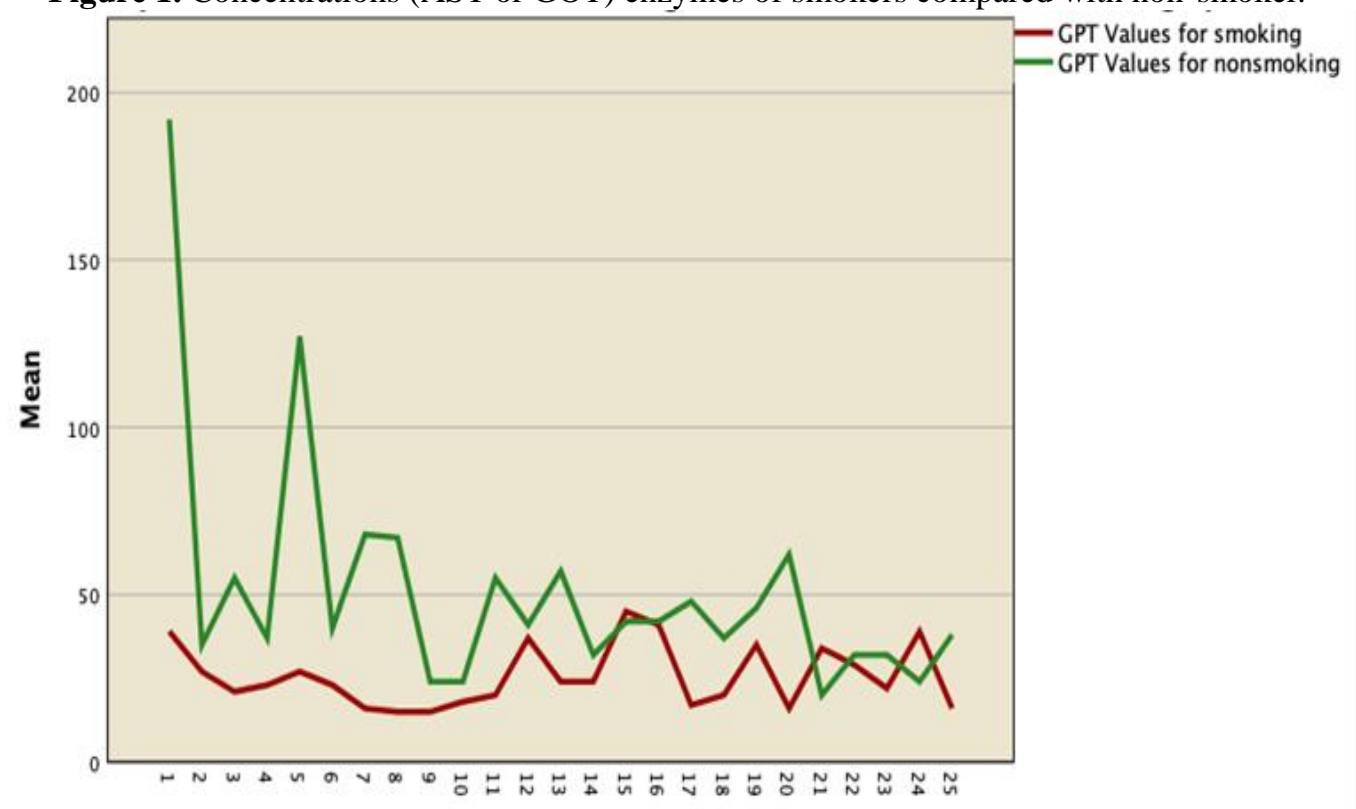

Figure 2. Concentrations (ALT or GPT) enzymes of smokers compared with a non-smoker.

Important changes in the activity concentrations of AST and ALT liver enzymes in smokers relative to non-smokers, and increases in proportion to the duration of smoking. So the liver enzymes AST and ALT in which increased due to exposure to smoke or duo to release a high level of the cellular oxidative radicals as reported in $[17,18]$. The enzyme that is important for producing energy is alanine aminotransferase (ALT or GPT), this enzyme is found in the liver and other tissues besides the liver but in fewer concentrations than its 
concentration in the liver, it is found for example in the heart and the skeletal muscles. In comparison to other liver enzymes can be used to diagnose liver diseases, such as in the diagnosis of hepatitis and cirrhosis [19].

\section{Conclusion}

The results show that cigarette smoking has an effect on the liver function that is expressed in the amount of liver enzyme secretion in the blood serum, so smoking can affect liver functions by affecting the secretion of AST and ALT liver enzymes, causing liver injury in the community of smokers compared to non-smokers. shows that the level of AST and ALT enzymes are higher in cigarette smokers when we compare them with non-smokers, and this may be related to the effect of smoking on the liver.

\section{References}

1. Mathers, C.D.; Loncar, D. 2006 Projections of global mortality and burden of disease from 2002 to 2030. PLoS Med. 2006, 3, e442.

2. Yeh, C.C.; Barr, R.G.; Powell, C.A.; Mesia-Vela, S.; Wang, Y.; Hamade, N.K.; Austin, J.H.; Santella. R.M. No effect of cigarette smoking dose on oxidized plasma proteins. Environ. Res. 2008 106, 219.

3. Aula, F.A.; Qadir, F.A. Effects of cigarette smoking on some immunological and hematological parameters in male smokers in Erbil city Jordan. J. Biol. Sci. 2013, 147, 1.

4. Preston. A. 1991. Cigarette smoking-nutritional implications. Progr. Food Nut. Sci. 1991 $15,183$.

5. Pessione, F.; Ramond, M.J.; Njapoum, C.; Duchatelle, V.; Degott, C.; Erlinger, S.; Rueff, B.; Valla, D.C.; Degos, F. Cigarette smoking and hepatic lesions in patients with chronic hepatitis C. Hepatology, 2001, 34, 121.

6. Yu, M.-W.; Hsu, F.-C.; Sheen, I.-S.; Chu, C.-M.; Lin, D.-Y.; Chen, C.-J.; Liaw. Y.-F. Prospective study of hepatocellular carcinoma and liver cirrhosis in asymptomatic chronic hepatitis B virus carriers. Am. J. Epidemiol. 1997, 145, 1039-1047.

7. Yuen, S.T.; Gogo, Jr. A.R.; Luk, I.S.; Cho, C.H.; Ho, J.C.; Loh, T.T. The effect of nicotine and its interaction with carbon tetrachloride in the rat liver. Pharmacol. Toxicol. 1995, 77, 225.

8. Husain, K.; Scott, B.R.; Reddy, S.K.; Somani, S.M. Chronic ethanol and nicotine interaction on rat tissue antioxidant defense system. Alcohol ,2001, 25, 89.

9. Watanabe, K.; Eto, K.; Furuno, K.; Mori, T.; Kawasaki, H.; Gomita, Y. 1995 Effect of cigarette smoke on lipid peroxidation and liver function tests in rats. Acta Medica Okayama, 1995, 49, 271.

10. El-Zayadi, A.R. Heavy smoking and liver. World J. Gastroenterol. WJG 2006, 12, 6098.

11. Young, C.J.; Moss. J.Smoke inhalation: diagnosis and treatment. J. Clinical Anesth. 1989 $1,377$.

12. Heimbach, D.M.; Waeckerle, J.F. Inhalation injuries. Ann. Emerg.Med. 1988, 17, 1316.

13. Gutteridge, J.M.; Halliwell, B. Iron toxicity and oxygen radicals Bailliere's. Clin. Haematol. 1989, 2, 195.

14. Farsalinos, K.E.; Romagna,G.; Allifranchini, E.; Ripamonti, E.; Bocchietto, E.; Todeschi, S.; Tsiapras. D.; Kyrzopoulos. S.; Voudris. V. 2013 Comparison of the cytotoxic potential of cigarette smoke and electronic cigarette vapour extract on cultured myocardial cells. Int. J. Environ. Res. Public Health 2013 10, 5146.

15. Chakraborty, A.; Selvaraj, S. Differential modulation of xenobiotic metabolizing enzymes by vanadium during diethylnitrosamine-induced hepatocarcinogenesis in Sprague-Dawley rats. Neoplasma ,2000, 47, 81 .

For more information about the Conference please visit the websites:

http://ihicps.com/

B i o l o g y $\mid \mathbf{5 5}$ 
16. Padmavathi, P.; Reddy, V.D.; Varadacharyulu, N. Influence of chronic cigarette smoking on serum biochemical profile in male human volunteers. J. Health Sci. 2009, 55, 265.

17. Abdul-Razaq, S.N.; Ahmed, B.M. Effect of cigarette smoking on liver function test and some other related parameters Zanco. J. Med. Sci. 2013, 17, 556.

18. Dhahir, N. K.; Noaman, A. A. 2017. Study effect of cigarette smoking on the liver functions and electrolytes. Iraqi J. Sci. $2017,58,211-215$.

19. Aubin, H.J.; Rollema, H.; Svensson, T.H.; Winterer, G. Smoking, quitting, and psychiatric disease: a review Neurosci. Biobehav. Rev. $2012,36,271$. 